\title{
Effect of unconventional by-product on growth performance, digestibility, carcass characteristics, blood profile and cecal microbial activity in New Zealand white rabbits
}

\author{
Yasmin M.M. Mahmoud \\ Ministry of Agriculture \\ Abd El-Kader Mahmoud Kholif ( $\square$ am_kholif2000@yahoo.co.uk ) \\ National Research Centre https://orcid.org/0000-0001-8207-6460 \\ Mabrouk Elsabagh \\ Kafrelsheigh University
}

\section{Research Article}

Keywords: Rabbits, unconventional by-products, growth performance, digestibility, carcass traits, blood profile, caecal activity

Posted Date: November 9th, 2021

DOI: https://doi.org/10.21203/rs.3.rs-1009341/v1

License: (c) (1) This work is licensed under a Creative Commons Attribution 4.0 International License.

Read Full License 


\section{Abstract}

This study addressed the effect of unconventional by-products on growth performance, carcass characteristics, some blood parameters, and caecal activities in New Zealand White (NZW) rabbits. A total of 48 weaned NZW rabbits (748 $\pm 9.50 \mathrm{~g} \mathrm{BW}, 6$ weeks old), randomly assigned into three treatment groups ( 16 each, individually housed), were fed a basal diet containing BBP at 0.00 (Control), 1.00 (Broc1) or 3.00 (Broc2) \% on a dry matter (DM) basis as feed additives, for 8 weeks. The Broc2 rabbits showed the highest $(P<0.05)$ body weight gain and feed intake followed by the Broc1 group compared to the control one. Feed conversion ratio and performance index did not differ $(P>0.05)$ among treatments. Nutrient digestibility was higher $(\mathrm{P}<0.05)$ for Broc1 and Broc2 rabbits compared to the control. Both Broc1 and Broc2 rabbits showed higher $(P<0.05)$ empty edible carcass, giblets, dressing, head, liver, heart and kidney weights, but showed a lower non-edible carcass weight compared to the control. Blood proteins and liver function enzymes were increased $(P<0.05)$ whereas the glucose, total cholesterol, uric acid and creatinine were decreased $(\mathrm{P}<0.05)$ in Broc1 and Broc2 rabbits compared to the control. The caecal concentration of total volatile fatty acids was increased $(P<0.05)$ but that of ammonia was decreased $(P<0.05)$ with Broc1 and Broc2 groups of rabbits compared to those of control. Thus, dietary supplementation of BBP at $3 \%$ of DM in rabbits' diets could improve their growth performance, carcass traits, liver function and blood profile as well as the caecal fermentation parameters.

\section{Introduction}

Currently, the profitability of animal production enterprises is threatened by shortages and price rises of conventional feedstuffs due to the negative impact of global climate change on agriculture production and the increasing food-feed-fuel competition for the same valuable limited resources. On the other side, there is an increasing demand for animal products worldwide. Therefore, the major challenge facing the livestock industry is the development of commercial, cost-effective diets using locally available, cheap and non-conventional/underutilized feed resources keeping in mind the environmental and product quality considerations. Recycling vegetable wastes into feeds for animals will contribute to animal feeding and human food security as well as to environmental health (Bakshi et al., 2016; Shurson, 2020).

Broccoli is a vegetable that belongs to the family Cruciferae and genus Brassica (Campas-Baypoli et al. 2009). Approximately $70 \%$ of the total weight of the broccoli is usually discarded in the fields generating high quantities of leaves, stalks and florets as crop residue of which a small percentage is used as animal feed without any kind of treatments (Campas-Baypoli et al. 2009). Broccoli by-products (BBPs) are palatable and nutritious feeds of adequate protein, fiber and ash contents as well as fatty acids (linolenic acid, palmitic acid and linoleic acid) and amino acids (tyrosine, aspartate, glutamate, proline and valine) (Campas-Baypoli et al., 2009; Panwar et al., 2017; Meneses et al., 2020). Also, BBPs are rich in glucosinolates and polyphenolic compounds as well as other bioactive components (e.g., carotenoids, flavonoids, and peroxidase) known for their health-promoting properties (Duarte-Va'zquez et al., 2007; Harbaum et al. 2007; Thomas et al., 2018). 
Few studies have been done on the utilization of BBPs as an alternative feed source; the major findings of these studies in various animals are described in the following section. Growth performance was improved in rabbits fed $6 \%$ BBPs as a substitute for alfalfa hay compared to those fed a control diet free from BBPs (Ibrahim et al. 2011). However, nutrient digestibility was decreased in broiler chickens fed $9 \%$ compared to 3 or $6 \%$ of dried broccoli floret (Mustafa and Baurhoo, 2016). Recently, in vitro assay indicated that dried broccoli residues (florets and stems) could replace up to $24 \%$ of the conventional concentrate (wheat, soybean meal and wheat bran) in ruminant diets without compromising rumen fermentation (de Evan et al., 2020).

Yet, the nutrient and bioactive compound profiles of BBPs deserve more investigation, particularly as a feed additive in animal feeds. This study, therefore, was designed to estimate the effect of BBPs, as a nontraditional feed additive, on growth performance, nutrient digestibility and feeding value, carcass traits, some blood parameters, and biochemical traits of caecal activity in rabbits.

\section{Materials And Methods}

\section{Broccoli by-product and experimental diets}

An adequate amount of BBPs (heads, leaves and false stems) was directly collected after harvest (moisture content 90\%), chopped into 2-3 cm pieces, sun-dried for 2 weeks and then grounded and stored until mixing with the other ingredients for formulating the experimental diets. The proximate composition of BBPs and the experimental diets was performed according to the Association of Official Analytical Chemists method (AOAC, 1996). Feed ingredients and the nutrient composition of the experimental diets are shown in Table 1. The experimental diets were formulated to be iso-caloric ( 2500 $\mathrm{kcal} \mathrm{DE} / \mathrm{kg}$ diet) and iso-nitrogenous ( 17\% CP). Diets were prepared in pellet form that included adequate levels of nutrients to fulfill the necessary nutrient for growing rabbits according to the Agriculture Ministry Decree (1996).

\section{Animals, experimental design, and management}

A total of 48 weaned NZW rabbits (748 $\pm 9.50 \mathrm{~g} \mathrm{BW}, 6$ weeks old) were individually housed in galvanized wire batteries and randomly assigned into three treatment groups (16 rabbits each) and fed one of 3 diets: control diet, basal diet free from BBPs (Broc0); basal diet plus 1\% BBPs (Broc1), or basal diet plus $3 \%$ BBPS (Broc2) as feed additives, on dry matter (DM) basis for 8 weeks. Rabbits were fed ad libitum with free access to fresh water via automatic drinkers with nipples for each battery. Rabbits were monitored daily and managed under the same environmental and hygienic conditions and were given the appropriate vaccinations. Feces and urine were cleaned every morning when dropped from the cages on the ground. At the beginning of the experiment, all rabbits were individually weighed, and then weekly before offering a meal in the morning until the $14^{\text {th }}$ week of age. The feed intake was recorded weekly throughout the feeding period of the experiment. The live body weight, body weight gain, feed 
consumption, feed conversion, and the performance index\% $(\mathrm{PI})=\{$ final live body weight $\mathrm{kg} / \mathrm{feed}$ conversion $\times 100\}$, were calculated accordingly.

\section{Digestibility trial}

In the last week of the feeding period of the experiment, 3 rabbits from each treatment group were randomly selected and individually housed in metabolic cages and received the same feeding regime and dietary treatments of the feeding trial. Individual feed intake was carefully determined, and the daily total amount of feces for each rabbit were taken every morning for the 7 - $d$ collection period. The feces were sprinkling with $2 \%$ boric acid as a trap for not releasing ammonia and were immediately frozen at $-20^{\circ} \mathrm{C}$ until the end of the collection phase and then composite samples for each rabbit were prepared for analysis. Feces of each rabbit were thoroughly mixed, dried at $60^{\circ} \mathrm{C}$ for 24 hours, then representative samples were prepared and kept until analysis. Diets and feces were analyzed for the proximate composition according to AOAC (1996) and digestion coefficients were calculated accordingly.

\section{Carcass traits}

On the final day of the feeding period of the experiment, 3 rabbits from each treatment group were randomly chosen and fasted for $12 \mathrm{hrs}$. Rabbits were weighed individually, and the pre-slaughter weight was recorded, and then the rabbits were slaughtered. After complete skinning and bleeding, the empty carcass with head, heart, kidneys and liver were weighed separately according to Cheeke (1987) to determine the carcass traits (empty carcass, giblets, dressing (total edible parts) and non-edible parts weights.

\section{Blood parameters}

Blood samples from slaughtered rabbits, 3 in each group, were taken in heparinized sterile tubes for each animal immediately after slaughtering and plasma was obtained by centrifugation at $3000 \mathrm{rpm}$ for 20 min and stored at $-20{ }^{0} \mathrm{C}$ until the analysis of blood parameters. Plasma was used for the determination of the total protein by the Biuret method according to Henry et al. (1974) and total albumin by Doumas et al. (1971), globulin concentration was calculated as the difference between the total protein and albumin. Creatinine was determined according to Henry et al. (1974) and plasma glucose was determined according to the procedure of Coles (1986). Plasma aspartate aminotransferase (AST) and alanine aminotransferase (ALT) activities were assayed according to the procedures of Reitman and Frankel (1957). Total cholesterol was determined according to Allian et al. (1974) using bio Merieux test kits, and uric acid was determined according to Tietz (1986). All biochemical blood constituents were determined using a spectrophotometer (Spectronic 21 DUSA) and commercial diagnostic kits (Combination, Pasteur Lap.).

\section{Caecal microbial activity}


At the end of the feeding period of the experiment, 3 rabbits of each treatment group were randomly selected, deprived of feed for 12 hours and then slaughtered for cecal contents sampling to measure cecal fluid $\mathrm{pH}$, ammonia nitrogen (NH3-N) and total volatile fatty acids (TVFAs). The cecal fluid samples were strained through four folds of gauze and the $\mathrm{pH}$ was immediately determined using the Bechman $\mathrm{pH}$ meter. The NH3-N concentration was determined using the micro-diffusion method according to Conway (1958). The TVFAs concentration in cecal contents juice, mixed with $1 \mathrm{ml} \mathrm{N} / 10 \mathrm{HCL}+2 \mathrm{ml}$ orthophosphoric acid/2 ml cecal fluid, was determined according to Eadie et al. (1967).

\section{Statistical analysis}

Data were evaluated using the one-way analysis of variance procedure (SAS, 2000) using the following fixed model:

$Y i=\mu+T i+i e$

Where $\mathrm{Yi}=$ The individual observation; $\mu=$ Overall mean; $\mathrm{Ti}=$ Effect of treatments. $(i=1,2$ and 3$) ; i e=$ Random error component assumed to be normally distributed. Differences between treatment means were detected by Duncan's multiple range test (Duncan, 1955). The results are presented as means \pm standard deviations. Significance was set at $P<0.05$.

\section{Results And Discussion}

\section{Chemical composition of the broccoli by-products}

Chemical analysis of BBP is presented in Table 2. Results showed that dried BBPs had an acceptable value of $\mathrm{CP}, \mathrm{CF}, \mathrm{EE}, \mathrm{NFE}$ and ash contents. Data showed that BBPs had higher contents of the CP $(24.9 \%)$ and ash (16.2\%) on a DM basis. These findings are similar to those obtained by Alpuche-Solis and Paredes-Lo'pez (1992) who found a relatively high protein content in floret flours (36.6\% of DM) and stalk flours (18.6\% of DM) and reported that the protein level measured in the whole plant flour of four cultivars of broccoli ranged from 23.2 to $32.0 \%$ of DM. Results obtained by Ibrahim et al. (2011) revealed that the chemical composition of BBPs for CP, CF, EE, NFE and ash, was 14.3, 23.9, 2.35, 45.9 and 13.6\%, respectively, being fairly similar in respect of EE and NFE with those recorded in the present work. Hu et al. (2012) reported higher CP content (27.1\%) and lower CF content (8.85\%) than those obtained in the present study (Table 2) for broccoli stem and leaf meal on a DM basis. In short, our findings suggest the possible incorporation of BBPs (heads, leaves and false stems) with potential added values to animal feed.

\section{Growth performance}

Effects of BBPs supplementation on growth performance parameters of NZW rabbits are presented in Table 3. Rabbits fed Broc2 diet showed the highest $(P<0.05)$ total body weight gain $(W G)$ and feed intake $(\mathrm{FI})$ at 10 and 14 weeks of age, followed by those fed the Broc 1 diet versus the control diet which showed the lowest WG and FI values. Previously, rabbits fed diets containing $6 \%$ broccoli residues as a 
substitute for alfalfa hay showed an improvement in the final body weight and daily gain compared to those fed a control diet free from broccoli residues, however, it had no significant effect on feed intake and feeding value (Ibrahim et al. 2011). In lactating dairy cows, replacing concentrate mixture with $20 \%$ pelletized BBPs had no adverse effects on rumen fermentation but increased milk production numerically and increased milk fat content significantly (Yi et al. 2015). In sheep, Mahmoud (2016) pointed out that both live body weight and daily gain were higher for lambs fed diets containing BBPs at a rate of 20 or $40 \%$ level in replacing to berseem hay. In contrast to our findings, Hu et al. (2011) indicated that increasing dietary inclusion $(0,3,6$, or $9 \%)$ of dried broccoli leaves and stem meal for the diets of laying hens had no significant effect on productive performance. It has been shown that BBPs contain high levels of vitamins $E$ and $C$, calcium and phosphorus, as well as the most valuable amino acids (Hu et al., 2012) in addition to glucosinolates, the bioactive compounds of Brassica vegetables (Gerendas et al., 2008). Thus, the growth-promoting effect of BBPs might be due to their good nutrient profile and their high content of bioactive compounds that promote productive performance (Gerendas et al. 2008; Hu et al. 2012; Vallejo et al. 2004). Madhu and Kochhar (2014) revealed that broccoli leaves are available at no cost and are rich in most micronutrients and macronutrients for the biological processes in animal feed.

Regarding the feed conversion (FC) and performance index, results showed no significant effect due to the addition of different levels of BBP into the diet of rabbits (Table 3). In contrast to our findings, Mahmoud (2016) concluded that the best FC $(P<0.05)$ was found with $40 \%$ BBP in replacing berseem hay for lambs, while the poorest one was associated with the control one. Also, Mustafa and Baurhoo (2016) reported that incorporation of dried broccoli floret residues at 3 and $6 \%$ levels increased the FC ratio in broiler chicken diets. In piglets (four weeks old male weaned piglets), broccoli extracts positively influenced WG and FC during the $1^{\text {st }}$ week of the experiment only and there were no significant differences in productive performance between the tested and control piglets over the whole trial period (Mueller et al. (2012). Regardless of the controversies among results that might be due to various factors, these findings emphasize that the utilization of vegetable residue is a sustainable move in animal production and environmental protection.

\section{Digestibility}

The effect of BBPs supplementation in the diets of rabbits on digestibility coefficients is summarized in Table 4. Data obtained indicated that DM, OM, CP, CF, EE and NFE digestibility for Broc1 and Broc2 diets was greater $(P<0.05)$ compared to those of the Broc0 diet. Accordingly, the feeding value in terms of total digestible nutrient (TDN) and digestible crude protein (DCP) was greater in both tested diets versus the control one. Similar results were reported by Mahmoud (2016) who indicated that digestion coefficients of CP and NFE and subsequently feeding values in terms of TDN and DCP were higher for lambs received diets containing BBPs at a rate of 20 or $40 \%$ level in replacing to berseem hay in their diets. Ibrahim et al. (2011) found that rabbits fed diets contained 3 or $6 \%$ BBPs replacing to alfalfa hay increased digestion coefficients of DM, CP and CF and feeding values (TDN and DCP) compared to the control diet, but no significant effect was recorded regarding digestibility coefficients of $\mathrm{OM}, \mathrm{EE}$ and NFE. The improved digestion coefficients in rabbits fed BBPs might be due to the improved 
caecal ecosystem and caecal morphology exerted by broccoli fiber as recorded by Paturi et al. (2010). In contrast, Mustafa and Baurhoo (2016) reported that dried broccoli floret residues incorporated at a rate of 3 or $6 \%$ did not affect nutrient digestibility. However, the ileal and total tract nutrient digestibility were compromised in broilers fed broccoli floret at a high level of $9 \%$ compared to in those fed the control diet (Mustafa and Baurhoo, 2016). Similarly, Mustafa and Baurhoo (2018) showed that the digestibility of $\mathrm{DM}, \mathrm{OM}$ and CP was decreased with increasing the level of dried broccoli floret from 0 to $12 \%$ in the diets of laying hens.

\section{Carcass traits}

Data of carcass traits of slaughtered NZW rabbits are presented in Table 5. Results revealed that insignificant differences were observed in pre-slaughter and non-edible parts weights due to the addition of different levels of BBPs in the diets of rabbits. The obtained results indicated that the weights of the empty carcass (with head), giblets and dressing (total edible parts) were higher $(P<0.05)$ for both Broc1 and Broc2 diets than those of the Broc0 diet. A similar trend among the dietary treatments was observed for head, liver, heart and kidney weights, with the highest values were found in the Broc2 diet and the low ones were associated with the Broc 0 diet. This improvement induced by the Broc2 diet might be due to the ability of BBPs in preventing fat deposition, especially in inedible offal as has been previously reported by An et al. (2010). In contrast, Ibrahim et al. (2011) revealed that rabbits fed a diet that contained $3 \%$ or $6 \%$ BBPs as a substitute for lucerne hay in their diet had no change in weights of inedible offal and carcass, digestive tract and chemical analysis of the 9,10 and $11^{\text {th }}$ ribs but has a lower dressing percentage in comparison to control rabbits.

\section{Blood biochemical parameters}

The results of the blood plasma biochemical parameters of rabbits are presented in Table 6. Total protein, albumin and globulin concentrations were higher $(P<0.05)$ for rabbits that received BBPs than those of the control one with the highest value was observed with the Broc2 diet. Inversely, plasma glucose, total cholesterol, uric acid and creatinine concentrations were lower $(P<0.05)$ with both tested diets than those of control one with the lowest value was associated with the Broc2 diet. Similarly, Mahmoud (2016) showed that lambs received BBPs at a rate of $40 \%$ in replacing to berseem hay increased the concentrations of total protein, albumin and triglyceride, while those received BBPs at a rate of $20 \%$ recorded the highest values of globulin, creatinine and total cholesterol compared with lambs received diet without any replacement. Kummer et al. (1981) showed that total protein and its fractions can be used as an indicator to estimate the ruminant nutritional and physiological cases, so, the increase in globulin production by the liver could reflect the good hepatic functions of these animals and correlates very well with high immunity (Griminger, 1986). In the same context, Craig (1999) mentioned that albumin is one of the important protein fractions that keeps the osmotic pressure stable in the blood. Both albumin and globulin results reflect the ability of animals to store reserve proteins even after their bodies have reached the maximum capacity of depositing tissues (Stroev, 1989). The present results are in harmony with those reported by Cox-Ganser et al. (1994) who recorded that transfer of sheep from 
grazing grass to Brassica forage results in a reduction in plasma cholesterol. Similar results in human patients were observed by Suido et al. (2002) who found that daily consumption of broccoli may be useful in lowering the low-density lipoprotein cholesterol levels in hypercholesterolemic.

The AST and ALT enzyme activity was higher $(P<0.05)$ in rabbits that received Broc1 and Broc2 diets in comparison with the control one. Additionally, Hu et al. (2011) mentioned that hepatic hydroxymethylglutaryl-coenzyme A (HMG-CoA) reductase activity was decreased with increasing dried broccoli leaves and stems meal supplementation. In general, the values obtained respecting blood constituents in this work indicated that all rabbit groups were under normal physiological and healthy status.

\section{Caecum activity}

The results concerning the caecal activities in terms of $\mathrm{pH}$ value, concentrations of TVFAs and $\mathrm{NH}_{3}-\mathrm{N}_{\text {are }}$ presented in Table 7. Results revealed no significant differences between treatments in cecal pH value. Rabbits fed Broc2 diet showed the highest $(P<0.05)$ concentrations of TVFAs while the lowest values occurred with rabbits that received either $1 \%$ BBP (Broc1) diet or those of control diet (Broc0). The concentration of ammonia followed the opposite trend of TVFAs among dietary treatments, but no significant difference was observed between $\mathrm{Broc} 0$ and Broc1 groups and both were significantly higher than that of the Broc2 diet. These results might be due to the glucosinolates content that is considered as an important class of organic compounds including nitrogen and sulfur in BBPs which are healthpromoting compounds (Vallejo et al. 2004). Similarly, Mahmoud (2016) recorded that the values of rumen $\mathrm{pH}$ and TVFAs concentration were increased, and the concentration of $\mathrm{NH} 3-\mathrm{N}$ was decreased with the increase of BBPs meal supplementation compared with the control lambs. Also, Yi et al. (2008) found little effect on in vitro gas production and ruminal fermentation in ruminant diets after replacing soybean meal with pelletized BPPs. In addition, Yi et al. (2015) indicated that replacing concentrate mixture with $20 \%$ pelletized BBPs had no adverse effects on rumen fermentation in lactating dairy cows. Moreover, it has been reported in rats that fermentable oligosaccharides in BBPs may be beneficial to cecal microbiota, alter the cecal TVFAs and increase the crypt depth and goblet cell number in the colon (Paturi et al. 2010) and thus protecting the gut ecosystem. Also, it has been revealed that BBP improved the utilization of a low protein diet by conferring some protection in terms of the colon morphology, via its antimicrobial properties against several microorganisms of clinical importance (Brandi et al. 2006; Paturi et al. 2010).

To this end, broccoli residues may vary in percentages of stalks, stems, leaves, and florets which in turn reflect the variation in the content of nutrient and antinutritional factors in broccoli restudies preparations. Broccoli residues contain the antinutritional compounds tannin, phytate and oxalate, saponins, goitrogens, and trypsin inhibitor (Madhu and Kochhar (2014; Nagraj et al., 2020) which negatively affect the assimilation of nutrients, particularly protein and minerals. A higher intake of broccoli residues may impair gut function and metabolic performance due to these antinutritional compounds (Choudhury and Khaled, 2014; Sinha and Khare, 2017; Nagraj et al., 2020). Further, the nutritional quality and the bioactive 
compounds in broccoli residues vary with broccoli cultivars, cultivation conditions, and pre-and postharvest processing (llahy et al., 2020). Thus, further studies are warranted on the biological effects of different preparations of broccoli residues on animal performance and health.

\section{Conclusion}

Based on our results, it could be concluded that using broccoli by-products as an additive in the diets of growing rabbits at a rate of $3 \%$ could improve productive performance, nutrient digestibility and carcass traits as well as enhance liver functions. This implies that $3 \%$ BBP may be useful as a suitable untraditional feed ingredient in feeding rabbits.

\section{Declarations}

\section{Compliance with ethical standards}

The current work was carried out at Sakha Animal Production Research Station, which belongs to the Animal Production Research Institute, Agriculture Research Center, Giza, Egypt. Laboratories works were carried out at APRI, Dokki, Giza, Egypt. All experimental procedures were reviewed and approved by Animal Production Research Institute, Agriculture Research Center, Giza, Egypt.

\section{Conflict of interest}

The authors declare that they have no conflict of interest.

\section{Funding}

The authors did not receive support from any organization for the submitted work.

Acknowledgments $Y M$ and $A M$ conceived and designed research. $Y M$ and $A M$ conducted experiments. YM and ME analyzed data. YM and AM wrote the manuscript. All authors read and approved the manuscript.

\section{Consent for publication}

Not applicable.

\section{Availability of data and material (data transparency)}

The authors declare that data supporting the findings of this study are available within the article

\section{Code availability}

Not applicable 


\section{References}

1. AOAC 1996. Association of Official Analytical Chemists. 16th edition, Washington, Official Methods of Analysis, USA.

2. Agriculture Ministry Decree 1996. The Standard Properties for Ingredients, Feed Additives and Feed Manufactured for Animal and Poultry, El-Wakaee.

3. Ahuja, I.; Borgen, B.H.; Hansen, M.; Honne, B.I.; Müller, C.; Rohloff, J.; Rossiter, J.T. and Bones, A.M. 2011. Oilseed rape seeds with ablated defense cells of the glucosinolate-myrosinase system.

Production and characteristics of double haploid MINELESS plants of Brassica napus L. J. Exp. Bot., 62(14): 4975-93.

4. Allian, C. C.; Poon, L. S.; Chan, C. S. G. and Richmond, W. 1974. Enzymatic determination of total serum cholesterol. Clin. Chem., 20:470-475.

5. Alpuche-Solis, A.G. and Paredes-Lo'pez, O. 1992. Assessment of glucosinolates in broccoli by three different methodologies. J. Food Biochem., 16(5):265-275.

6. An, S.; Han, J.I.; Kim, M.J.; Park, J.S.; Han, J.M.; Baek, N.I.; Chung, H.G.; Choi, M.S.; Lee, K.T. and Jeong, T.S. 2010. Ethanolic extracts of Brassica campestris spp. Rapa roots prevent high-fat dietinduced obesity via beta (3)-adrenergic regulation of white adipocyte lipolytic activity. J. Med. Food, 13(2): 406-414.

7. Bakshi, M.; Wadhwa, M. and Makkar, P. 2016. Waste to worth: Vegetable wastes as animal feed. CAB Rev. Perspect. Agric. Vet. Sci. Nutr. Nat. Resour. 11, 1-26.

8. Brandi, G.; Amagliani, G.; Schiavano, G.F.; De Santi, M. and Sisti, M. 2006. The activity of Brassica oleracea leaf juice on food-borne pathogenic bacteria. J. Food Prot., 69(9): 2274-2279.

9. Campas-Baypoli, O.N.; Sánchez-Machado, D.I.; Bueno-Solano C.; Núñez-Gastélum J.A.; Reyes-Moreno C. and López-Cervantes J. 2009. Biochemical composition and physicochemical properties of broccoli flours. Int J Food Sci Nutr 60: 163-73.

10. Cheeke, P.R. 1987. Rabbit Feeding and Nutrition. Academic Press. Orlando, Florida, U. S.A.

11. Choudhury, S.P. and Khaled, K.L. 2014. Estimation of antioxidant and antinutritional factors of green broccoli florets and their effects on boiling. Am. Int. J. Res. Form. Appl. Nat. Sci. 8, 41-43.

12. Coles, E.H. 1986. Veterinary Clinical Pathology. 4th ed., W.B. Saunders Company. Philadelphia, London, Toronto, Mecclco City, Rio de Janeiro, Syney and Tokyo.

13. Conway, E.F. 1958. Micro-diffusion analysis and volumetric error (4th Ed). The McMillan Co., New York.

14. Cox-Ganser, J.M.; Jung, G.A.; Pushkin, R.T. and Reid, R.L. 1994. Evaluation of Brassica in grazing systems for sheep: II. Blood composition and nutrient status. J. Anim. Sci., 72: 1832-2842.

15. Craig, W.J. 1999. Health-promoting properties of common herbs. American Journal of Clinical Nutrition, 70, (3): 491S-499S.

16. de Evan T.; Marcos C.N.; Ranilla M..J and Carro, M.D. 2020. In Vitro and In Situ Evaluation of Broccoli Wastes as Potential Feed for Ruminants. Animals. 2020; 10(11):1989. 
https://doi.org/10.3390/ani10111989.

17. Doumas, B.T.; Watson, W.A. and Biggs, H.G. 1971. Albumin standards and measurement of serum with bromocresol green. Clin. Chem. Acta, 31(1): 87-96.

18. Duarte-Va'zquez, M.A.; García-Padilla, S.; Garci'a-Almenda'rez, B.E.; Whitaker, J.R. and Regalado, C. 2007. Broccoli processing wastes as a source of peroxidase. J Agric Food Chem 55(25):10396_10404.

19. Duncan's, D.B. 1955. Multiple ranges and multiple F-test. Biometric., 11:1-42.

20. Eadie, J.M.; Hobson, P.N. and Mann, S.O. 1967. A note on some comparisons between the rumen content of barely fed steers and that of young calves also fed on high concentrate rations. J. Anim. Prod., 9: 247.

21. Gerendas, J.; Breuning, S.; Stahl, T.; Mersh-Sundermann, V. and Muhling, K.H. 2008. Isothiocyanate concentration in Kohlrabi (Brassica oleracea L. Var. gongylodes) plants as influenced by sulfur and nitrogen supply. J. Agric. Chem., 24,56 (18): 8334-8342.

22. Griminger, P. 1986. Lipid Metabolism in "AVIAN PHYSIOLOGY" Edited by P.D. Sturkie. 4th ed. SpringerVerlag, Inc., New Work, NY.

23. Harbaum, B.; Hubbermann, E.M.; Wolf, C.; Herges, R.; Zhu, Z. and Schwarz, K. 2007. Identification of flavonoids and hydroxycinnamic acids in pak choi varieties (Brassica campestris L. ssp. Chinensis var. communis) by HPLC-ESI-MS and NMR and their quantification by HPLC-DAD. J Agric Food Chem 55(20):8251_8260.

24. Henry, R. J.; Cannon, D. C. and Winkelman, W. 1974. Clinical chemistry principals and techniques, 11th ed. New York: Happer and Row Publishers.1629.

25. Hu, C.H.; Zuo, A.Y.; Wang, D.G.; Pan, H.Y.; Zheng, W.B.; Qian, Z.C. and Zou, X.T. 2011. Effects of broccoli stems and leaves meal on production performance and egg quality of laying hens. Anim. Feed Sci. and Technol., 170:117-121.

26. Ibrahim, Sh. A.M.; Omer, H.A.A.; Ali, F.A.F. and El-Kady, R.I. 2011. Broccoli By-Products as a Partial Replacement of Lucerne Hay in Rabbit Diets Containing Different Levels of Protein. AmericanEurasian J. Agric. \& Environ. Sci., 11 (5): 685-696.

27. Ilahy, R.; Tlili, I.; Pék, Z.; Montefusco, A.; Siddiqui, M. W.; Homa, F.; Hdider, C.; R'Him, T.; Lajos, H. and Lenucci, M. S. (2020). Pre- and Post-harvest Factors Affecting Glucosinolate Content in Broccoli. Frontiers in nutrition, 7, 147. https://doi.org/10.3389/fnut.2020.00147

28. Kummer, N.; Snigh, U.B. and Verma, D.N. 1981. Effect of different level of dietary protein and energy on growth of male buffalo calves. Indian J. Anim. Sci., 51: 513.

29. Losada, H.; Corte's, J. and Grande, D. 1992. El uso de hortalizas en la produccio'n de leche en sistemas suburbanos. Livest Res Rural Dev 4(3). Available online at:http://www.cipav.org.co/index.php?option=com_wrapper\&ltemid=64(accessed 5 May 2007).

30. Madhu and Anita Kochhar 2014. Proximate composition, available carbohydrates, dietary fibre and anti-nutritional factors of Broccoli (Brassica oleracea I var. Italica plenca) leaf and floret powder. Biosci. Disc., 5(1):45-49. 
31. Mahmoud, M.M. Yasmin (2016). Using broccoli plant wastes in sheep rations. Egyptian J. Nutrition and Feeds., 19 (2):277-287.

32. Meneses, M.; Martínez-Marín, A.L.; Madrid, J.; Martinez-Teruel, A.; Hernandes, F. and Magias, M.D. 2020. Ensilability, in vitro and in vivo values of the agro-industrial by-products of artichoke and broccoli. Environ Sci Pollut Res 27, 2919-2925. https://doi.org/10.1007/s11356-019-07142-2

33. Mueller, K.; Nicole M. Blum; Kluge H.; Bauerfeind, R.; Julia Froehlich; Anneluise Mader; Karola R. Wendler and Andreas S. Mueller 2012. Effects of broccoli extract and various essential oils on intestinal and faecal microflora and on xenobiotic enzymes and the antioxidant system of piglets. Open J. of Anim. Scie., 2 (2):78-98.

34. Mustafa, A. F. and Baurhoo, B. 2016. Effects of feeding dried broccoli floret residues on performance, ileal and total digestive tract nutrient digestibility, and selected microbial populations in broiler chickens. J. of Appl. Poult. Rsear. 25 (4), 561-570.

35. Mustafa, A. F. and Baurhoo, B. 2018. Effect of Feeding Broccoli Floret Residues on Leghorn Layer Performance and Egg Quality and Nutrient Digestibility. British Poultry science, 59 (4):430-434.

36. Nagraj, G.S.; Chouksey, A.; Jaiswal, S. and Jaiswal, A.K. 2020. Broccoli. In Nutritional Composition and Antioxidant Properties of Fruits and Vegetables; Jaiswal, A.K., Ed.; Academic Press: Cambridge, MA, USA. Volume 1, pp. 5-17.

37. North, M.O. (1981). Commercial Chicken Production Manual. 3rd Ed, Avi., Publishing Company. I.N.C. Westport Connecticut, USA.

38. Panwar, V.S.; Sheoran Vinus, N. and Tewatia, B.S. 2017. Chemical composition and nutritive value of broccoli crop residue in goats. For. Res. 43, 50-53.

39. Paturi, G.; Butts, C.; Monro, J.; Nones, K.; Martell, S.; Butler, R. and Sutherland, J. 2010. Cecal and colonic responses in rats fed 5 or $30 \%$ corn oil diets containing either $7.5 \%$ broccoli dietary fiber or microcrystalline cellulose. J. Agric. Food Chem., 26, 58(10): 6510-6515.

40. Reitman, S. and Frankel, S. 1957. A colorimetric method for determination of serum glumaticoxaloacetic and glutamic pyruvic transaminases. Ann. Journal of clinical pathology:26:113.

41. SAS Institute Inc. 2000. SAS-User's Guide: Statistics. SAS Instute Inc., Cary, NC., USA.

42. Shurson, Gerald C. 2020. What a Waste"-Can We Improve Sustainability of Food Animal Production Systems by Recycling Food Waste Streams into Animal Feed in an Era of Health, Climate, and Economic Crises?" Sustainability 12, no. 17: 7071. https://doi.org/10.3390/su12177071

43. Sinha, K. and Khare, V. 2017. Review on: antinutritional factors in vegetable crops. Pharma Innov J, $12,353-358$.

44. Stroev, E. A. 1989. Biochemistry Text Book, MIR Publishers, MOSCOW.

45. Suido, H.; Tanaka, T.; Tabei, T.; Takeuchi, A.; Okita, M.; Kishimoto, T.; Kasayama, S. and Higashino, K. 2002. A mixed green vegetable and fruit beverage decreased the serum level of low density lipoprotein cholesterol in hypercholesterolemic patients. J. Agric. Food Chem., 22, 50(11): 33463350 . 
46. Tietz, N. W. 1986. Text book of Clinical Chemistry, Saunders, Philadelphia.

47. Thomas, M.; Badr, A.; Desjardins, Y.; Gosselin, A. and Angers, P. (2018). Characterization of industrial broccoli discards (Brassica oleracea var. italica) for their glucosinolate, polyphenol and flavonoid contents using UPLC MS/MS and spectrophotometric methods. Food Chemistry

48. US Department of Agriculture 2008. USDA national nutrient database for standard reference. Release 21. Nutrient Data Laboratory, Agricultural Research Service. Available online at: http://www.nal.usda.gov/fnic/foodcomp/search/. Accessed 15 June 2007.

49. USDA 2011. Nutritive value of broccoli leaves (cited from http://nutritiondata.self.com/facts/vegetables-and-vegetables products/broccoli/leaves).

50. Vallejo, F.; Gil-Izquierdo, A.; Pérez-Vicente, A. and García-Viguera, C. 2004. In vitro gastrointestinal digestion study of broccoli inflorescence phenolic compounds, glucosinolates and vitamin C. J. Agric. Food Chem., 14, 52(1): 135-138.

51. Yi, X.W.; Yang, F.; Chen, Y.; Liu, J.X. and Wang, J.K. 2015. Effects of replacement of concentrate mixture by broccoli by-products on lactating performance in dairy cows. Asian-Australas J. Anim. Sci., 28(10):1449-1453.

\section{Tables}

Table (1): Ingredients and calculated chemical composition of the experimental diet (as fed). 


\begin{tabular}{|c|c|}
\hline Item & Experimental diet \\
\hline \multicolumn{2}{|l|}{ Ingredients (\%): } \\
\hline Clover hay (12\%CP) & 30.00 \\
\hline Barley & 17.00 \\
\hline Yellow corn & 10.00 \\
\hline Soybean meal (44\%CP) & 17.00 \\
\hline Wheat bran & 20.00 \\
\hline Molasses & 3.50 \\
\hline DL-Methionine & 0.10 \\
\hline Vitamins \& minerals mixture $^{1}$ & 0.50 \\
\hline Salt & 0.50 \\
\hline Limestone & 1.05 \\
\hline Di-Calcium phosphate & 0.35 \\
\hline Total & 100 \\
\hline \multicolumn{2}{|l|}{ Calculated analysis: } \\
\hline Dry matter (DM), \% & 87.10 \\
\hline Crude protein (CP), \% & 17.08 \\
\hline Ether extract (EE), \% & 2.41 \\
\hline Nitrogen free extract (NFE), \% & 48.27 \\
\hline Ash, \% & 5.82 \\
\hline Digestible energy (DE) , kcal/kg & 2513 \\
\hline Crude fiber (CF), \% & 13.52 \\
\hline $\mathrm{NDF}, \%$ & 37.81 \\
\hline$A D F, \%$ & 21.76 \\
\hline Calcium, \% & 1.01 \\
\hline Total phosphorus, \% & 0.52 \\
\hline Methionine, \% & 0.36 \\
\hline Lysine, \% & 0.82 \\
\hline DE:CP & 147.11 \\
\hline
\end{tabular}


1- Supplied per Kg. of diet: 12000 IU Vit. A; 2200 IU D3; 10mg Vit.E; 2.0 mg Vit.K3; 1.0 mg Vit.B1; 4.0 mg Vit.B2; 1.5 mg Vit.B6; 0.0010mg Vit.B12; 6.7 mg Vit. Pantothenic acid;6.67 mg Vit. B5; 1.07mg Biotin; 1.67 mg Folic acid; 400 mg Choline chloride; 22.3 mg Zn;10 mg Mn; 25 mg Fe; 1.67 mg Cu; 0.25mg I; 0.033 mg Se and $133.4 \mathrm{mg} \mathrm{Mg.l.}$

Table (2). Proximate chemical analysis of broccoli by-product used in the experimental diets (\% DM basis).

\begin{tabular}{|c|c|c|c|c|c|c|c|}
\hline \multirow[t]{3}{*}{ Broccoli by-product } & \multicolumn{7}{|l|}{ Items } \\
\hline & DM & $\mathrm{OM}$ & $\mathrm{CP}$ & $\mathrm{CF}$ & $\mathrm{EE}$ & NFE & Ash \\
\hline & 92.50 & 83.77 & 24.86 & 12.95 & 1.16 & 44.80 & 16.23 \\
\hline
\end{tabular}

Table 3 Effects of dietary supplementation of broccoli by-products on growth performance of growing NZW rabbits at different ages 


\begin{tabular}{|c|c|c|c|c|c|}
\hline \multirow[t]{2}{*}{ Item } & \multicolumn{3}{|c|}{ Experimental diets } & \multirow[t]{2}{*}{ \pm SE } & \multirow[t]{2}{*}{$P$ value } \\
\hline & Broc0 & Broc1 & Broc2 & & \\
\hline \multicolumn{6}{|c|}{ Initial body weight (g) } \\
\hline 6 weeks & $729.17^{b}$ & $759.00^{a}$ & $754.58^{a}$ & \pm 5.44 & 0.0446 \\
\hline 10 weeks & $1347.50^{b}$ & $1385.00^{a b}$ & $1410.83^{a}$ & \pm 10.03 & 0.0297 \\
\hline 14 weeks & $1958.75^{b}$ & $2024.17^{a b}$ & $2097.92^{a}$ & \pm 17.52 & 0.0027 \\
\hline \multicolumn{6}{|c|}{ Total weight gain $(\mathrm{g})$} \\
\hline 6-10 weeks & 618.33 & 625.00 & 656.25 & \pm 10.90 & 0.3507 \\
\hline 10-14 weeks & $611.25^{b}$ & $639.17^{a b}$ & $687.08^{a}$ & \pm 14.35 & 0.0895 \\
\hline 6-14 weeks & $1229.58^{b}$ & $1264.17 \mathrm{ab}$ & $1343.33^{a}$ & \pm 18.53 & 0.0343 \\
\hline \multicolumn{6}{|c|}{ Total feed intake (g) } \\
\hline 6-10 weeks & 1965.83 & 1942.08 & 1982.50 & \pm 6.75 & 0001 \\
\hline 10-14 weeks & $3094.58^{c}$ & $3237.09 \mathrm{~b}$ & $3412.92^{a}$ & \pm 17.17 & 0001 \\
\hline 6-14 weeks & $5060.42^{c}$ & $5179.17^{b}$ & $5395.42^{a}$ & \pm 22.73 & 0001 \\
\hline \multicolumn{6}{|c|}{ Feed conversion ratio (g feed/g gain) } \\
\hline 6-10 weeks & 3.24 & 3.12 & 3.03 & \pm 0.162 & 0.6902 \\
\hline 10-14 weeks & 5.23 & 5.13 & 5.00 & \pm 0.280 & 0.9482 \\
\hline 6-14 weeks & 4.19 & 4.12 & 4.02 & \pm 0.110 & 0.6264 \\
\hline \multicolumn{6}{|c|}{ Performance index ${ }^{1} \%$} \\
\hline 6-10 weeks & 42.63 & 44.61 & 46.76 & \pm 2.37 & 0.7603 \\
\hline 10-14 week & 39.09 & 40.21 & 42.26 & \pm 2.02 & 0.4640 \\
\hline 6-14 weeks & 47.95 & 49.60 & 52.24 & \pm 1.78 & 0.2642 \\
\hline
\end{tabular}

Means bearing different letter superscripts $(a, b$ and $c)$ within the same row are significantly $(P \leq 0.05)$; $n=16$ 
${ }^{1}$ Performance index $\%$ = final live body weight $(\mathrm{Kg}) /$ feed conversion* 100 ; Calculated according to North (1981).

Broc0 = group fed the basal diet (control), Broc1 = group fed the basal diet with (1\% BBP) and Broc2= group fed the basal diet with (3\% BBP).

Table 4 Effects of dietary supplementation of broccoli by-products on digestion coefficients of nutrients and feeding values in growing NZW rabbits

\begin{tabular}{|c|c|c|c|c|c|}
\hline \multirow[t]{2}{*}{ Item } & \multicolumn{3}{|c|}{ Experimental diets } & \multirow[t]{2}{*}{ $\pm S E$} & \multirow[t]{2}{*}{$P$ value } \\
\hline & Broc0 & Broc1 & Broc2 & & \\
\hline \multicolumn{6}{|c|}{ Digestibility (\%) } \\
\hline DM & $67.75^{b}$ & $73.52^{a}$ & $74.93^{a}$ & \pm 1.20 & 0.0052 \\
\hline $\mathrm{OM}$ & $68.57^{b}$ & $74.04^{a}$ & $76.51^{a}$ & \pm 1.25 & 0.0019 \\
\hline $\mathrm{CP}$ & $69.06^{b}$ & $74.53^{a}$ & $76.68^{a}$ & \pm 1.21 & 0.0017 \\
\hline $\mathrm{CF}$ & $46.40^{b}$ & $53.34^{a}$ & $57.48^{a}$ & \pm 1.79 & 0.0062 \\
\hline $\mathrm{EE}$ & $76.43^{b}$ & $80.26^{a}$ & $81.84^{a}$ & \pm 0.843 & 0.0008 \\
\hline NFE & $73.61^{b}$ & $78.79^{a}$ & $80.98^{a}$ & \pm 1.16 & 0.0016 \\
\hline \multicolumn{6}{|c|}{ Feeding values: } \\
\hline TDN & $66.68^{b}$ & $71.94^{a}$ & $74.29^{a}$ & \pm 1.20 & 0.0018 \\
\hline DCP & $13.14^{b}$ & $14.18^{a}$ & $14.59^{a}$ & \pm 0.0 .230 & 0.0017 \\
\hline
\end{tabular}

Means bearing different letter superscripts $(a, b$ and $c)$ within the same row are significantly $(P \leq 0.05)$; $n=3$

Broc0 = group fed the basal diet (control), Broc1 = group fed the basal diet with $(1 \% \mathrm{BBP})$ and Broc2= group fed the basal diet with (3\% BBP).

Table 5 Effects of dietary supplementation of broccoli by-products on carcass traits in growing NZW rabbits 


\begin{tabular}{|c|c|c|c|c|c|}
\hline \multirow[t]{2}{*}{ Item } & \multicolumn{3}{|c|}{ Experimental diets } & \multirow[t]{2}{*}{ \pm SE } & \multirow[t]{2}{*}{$P$ value } \\
\hline & Broc0 & Broc1 & Broc2 & & \\
\hline Pre-slaughter (Fasted) (g) & 1981.67 & 2106.67 & 2133.33 & \pm 33.81 & 0.1422 \\
\hline Empty carcass wt. (g) & $1058.33^{b}$ & $1182.33^{a}$ & $1256.33^{a}$ & \pm 32.15 & 0.0072 \\
\hline Giblets (g) & $96.70^{c}$ & $104.40^{b}$ & $107.27^{a}$ & \pm 1.60 & 0.0001 \\
\hline Dressing (Total edible parts) (g) & $1155.03^{b}$ & $1286.73^{a}$ & $1363.60^{a}$ & \pm 33.62 & 0.0058 \\
\hline Nonedible parts (g) & 826.63 & 819.93 & 769.73 & \pm 17.27 & 0.3889 \\
\hline Head wt. (g) & $98.33^{b}$ & $116.67^{a}$ & $125.00^{a}$ & \pm 4.17 & 0.0012 \\
\hline Liver wt. (g) & $75.33^{c}$ & $81.27^{\mathrm{b}}$ & $83.67^{a}$ & \pm 1.28 & 0.0003 \\
\hline Heart wt. (g) & $7.20^{b}$ & $7.97^{a b}$ & $8.27^{a}$ & \pm 0.164 & 0.0002 \\
\hline kidneys wt. (g) & $14.17^{b}$ & $15.17^{a}$ & $15.33^{a}$ & \pm 0.200 & 0.0052 \\
\hline
\end{tabular}

Means bearing different letter superscripts $(a, b$ and $c)$ within the same row are significantly $(P \leq 0.05)$; $n=3$

Total edible parts wt. $=$ Empty carcass wt. $($ with head $)+$ edible giblets Wt.

Edible giblets Wt. $=$ Liver wt. + Kidneys wt. + Heart wt.

Total edible parts $\%=$ Total edible parts wt. / Fasted wt. *100

Broc0 $=$ group fed the basal diet (control), Broc1 = group fed the basal diet with $(1 \% \mathrm{BBP})$ and Broc2= group fed the basal diet with (3\% BBP).

Table 6 Effects of dietary supplementation of broccoli by-products on some blood parameters in growing NZW rabbits 


\begin{tabular}{|c|c|c|c|c|c|}
\hline \multirow[t]{2}{*}{ Item } & \multicolumn{3}{|c|}{ Experimental diets } & \multirow[t]{2}{*}{ $\pm S E$} & \multirow[t]{2}{*}{$P$ value } \\
\hline & Broc0 & Broc1 & Broc2 & & \\
\hline Total protein $(\mathrm{g} / \mathrm{dl})$ & $6.00^{c}$ & $6.53^{b}$ & $6.79^{a}$ & \pm 0.116 & 0.0001 \\
\hline Albumin $(\mathrm{g} / \mathrm{dl})$ & $3.64^{c}$ & $3.71^{b}$ & $3.81^{\mathrm{a}}$ & \pm 0.027 & 0.0017 \\
\hline Globulin (g/dl) & $2.36^{c}$ & $2.81^{b}$ & $2.97^{a}$ & \pm 0.092 & 0.0001 \\
\hline Glucose (mg/dl) & $100.00^{a}$ & $95.32^{b}$ & $94.43^{b}$ & \pm 1.05 & 0.0352 \\
\hline Total cholesterol $(\mathrm{mg} / \mathrm{dl})$ & $115.60^{a}$ & $101.10^{b}$ & $195.0^{b}$ & \pm 3.27 & 0.0001 \\
\hline Uric acid (mg/ dl) & $9.82^{a}$ & $7.16^{b}$ & $6.34^{c}$ & \pm 0.527 & 0.0001 \\
\hline Creatinine (mg/dl) & $2.06^{a}$ & $1.93^{\mathrm{ab}}$ & $1.89^{b}$ & \pm 0.033 & 0.0414 \\
\hline Activity of AST (U/I) & $38.67^{c}$ & $45.32^{a}$ & $49.41^{\mathrm{a}}$ & \pm 1.58 & 0.0001 \\
\hline Activity of ALT (U/I) & $30.64^{c}$ & $34.21^{b}$ & $37.37^{a}$ & \pm 0.998 & 0.0002 \\
\hline
\end{tabular}

Means bearing different letter superscripts $(a, b$ and $c)$ within the same row are significantly $(P \leq 0.05)$ different; $n=3$

Broc0 = group fed the basal diet (control), Broc1 = group fed the basal diet with (1\% BBP) and Broc2= group fed the basal diet with (3\% BBP).

Table 7 Effects of dietary supplementation of broccoli by-products on cecal microbial activity in growing NZW rabbits

\begin{tabular}{|llllll|}
\hline Item & \multicolumn{3}{l|}{ Experimental diets } & & \\
& Broc0 & Broc1 & Broc2 & \pm SE & P value \\
\hline $\mathrm{pH}$ & 7.17 & 7.17 & 7.1 & \pm 0.054 & 0.7928 \\
\hline TVFAs $(\mathrm{mq} / \mathrm{dl})$ & $1.10^{\mathrm{b}}$ & $1.20^{\mathrm{b}}$ & $1.40^{\mathrm{a}}$ & \pm 0.049 & 0.0055 \\
\hline Ammonia $(\mathrm{mq} / \mathrm{dl})$ & $23.52^{\mathrm{a}}$ & $23.05^{\mathrm{a}}$ & $16.80^{\mathrm{b}}$ & \pm 1.105 & 0.0001 \\
\hline
\end{tabular}

Means bearing different letter superscripts ( $a$ and $b)$ within the same column are significantly $(P \leq 0.05)$ different; $n=3$

Broc0 = group fed the basal diet (control), Broc1 = group fed the basal diet with (1\% BBP) and Broc2= group fed the basal diet with (3\% BBP). 